Check for updates

Cite this: RSC Adv., 2019, 9, 27996

Received 7th July 2019

Accepted 29th August 2019

DOI: 10.1039/c9ra05154f

rsc.li/rsc-advances

\section{Unorthodox synthesis, biological activity and DFT studies of novel and multifunctionalized naphthoxocine derivatives $\uparrow$}

\author{
Mohamed Ahmed Abozeid, (iD ${ }^{a}$ Aya Atef El-Sawi, ${ }^{a}$ Mohamed Ramadan Elmorsy, (iD ${ }^{a}$ \\ Mohamed Abdelmoteleb, (D) ${ }^{\text {bc }}$ Abdel-Rahman Hassan Abdel-Rahman ${ }^{a}$ \\ and El-Sayed Ibrahim El-Desoky (D)*a
}

A new promising protocol has been developed for the synthesis of scarce oxocine derivatives $3 a-e$ and 6 through addition of amine-based nucleophiles such as hydroxylamine hydrochloride, primary amine and hydrazide to chromonylidene benzothiazol-2-ylacetonitrile 2 in refluxing dioxane under metal free reaction conditions in moderate to good yields. Other nitrogen nucleophiles such as piperidine, hydrazine and thiosemicarbazide failed to afford the corresponding oxocinols, and instead pyridine derivatives 7, 8 and 10 were obtained exclusively. Predictive study for the biological activities using PASS (prediction of activity spectra for biologically active substances) online software showed optimistic activities for oxocinols $3 a-e$ in the treatment of cancer, influenza $A$ and microbial infections. Additionally, DFT studies of oxocine derivatives $3 a-e$ and 6 indicated the presence of required thermodynamics parameters for the application in dye-sensitized solar cells (DSSCs).

\section{Introduction}

The medium sized ( 7 to 9 membered) cyclic ethers are biologically interesting as well as challenging organic skeletons due their occurrence in numerous bioactive natural products in addition to their complex and macrocyclic structure which hinder their synthesis. ${ }^{1}$ In this class of macro- and heterocycles, oxocine constitutes a common scaffold in different biologically active natural products such as heliannoul $\mathrm{H}$, acremine $\mathrm{G}$ and protosapannin $\mathrm{B}$ in addition to alkaloids such as murraya and arcyroxocin (Fig. 1). ${ }^{2-8}$

Consequently, many chemists have paid increased attention to develop new methodologies in order to build up this promising scaffold over the last ten years such as (1) retro-Claisen rearrangement, ${ }^{9}$ (2) ring closing olefin metathesis ${ }^{10}$ (3) Nicatalyzed reductive Heck reaction, ${ }^{6}$ (4) DABCO-mediated [4+4] domino annulation of ynone and $\alpha$-cyano- $\alpha, \beta$-unsaturated ketone, ${ }^{7}$ (5) Lewis acid promoted acetal-alkene cyclization, ${ }^{\mathbf{1 1}}$ and others. ${ }^{12-23}$ However, even in the presence of these various protocols, many observable drawbacks have been encountered

${ }^{a}$ Department of Chemistry, Faculty of Science, Mansoura University, Mansoura-35516, Egypt. E-mail: prof.desoky.orgchem@gmail.com; Fax: +20502246254; Tel: $+201060614054$

${ }^{b}$ Food Allergy Research \& Resource Program (FARRP), Department of Food Science \& Technology, University of Nebraska, Lincoln, NE, USA

${ }^{c}$ Department of Botany, Faculty of Science, Mansoura University, Mansoura-35516, Egypt

$\dagger$ Electronic supplementary information (ESI) available. See DOI: 10.1039/c9ra05154f such as applying drastic conditions, using precious heavy metal catalysts, needing to have finely designed starting materials and tedious purification. Therefore, it would be worthy to develop new cost effective and functional group tolerant synthetic methodology toward oxocine framework.

In the view of the aforementioned natural occurrence and biological importance of oxocine heterocyclic compounds, we herein report our recent findings in the synthesis of oxocine derivatives via simple and novel domino nucleophilic addition of amine-based nucleophiles to chromonylidene benzothiazol2-ylacetonitrile 2 affording the corresponding oxocine derivatives $\mathbf{3 a}-\mathbf{e}$ and $\mathbf{6}$ in moderate to good yields.

\section{Results and discussion}

\section{Chemistry}

The acid mediated condensation of formylbenzochromone 1 (ref. 24) with 2-cyanomethyl-1,3-benzothiazole afforded the corresponding E,Z-mixture of 2-cyano-2-(1,3-benzothoazol-2-yl)3 -vinylnaphthopyran-4-one (2) in 90\% yield (Scheme 1). Under

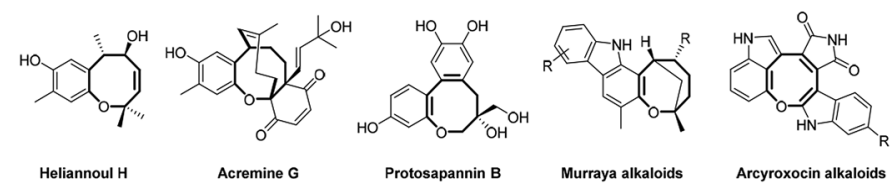

Fig. 1 Representative examples of biologically active oxocine natural products. 


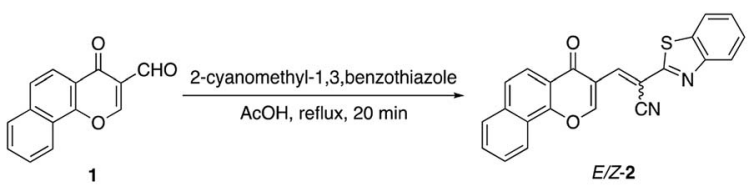

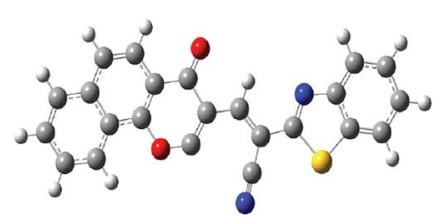

$E-2$

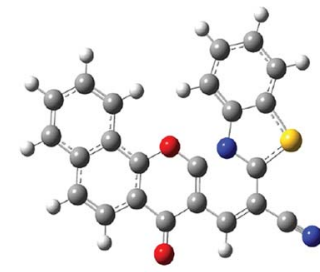

$Z-2$
Scheme 1 Synthesis and energy-optimized geometrical structures of $E$ - and Z-chromonylidene 2 .

acidic reaction conditions, equimolar E,Z-mixture of chromonylidene benzothiazol-2-ylacetonitrile 2 was obtained. The formation of both isomers in almost equal amounts might be rationalized to the absence of energy barrier between both isomers due to the presence of bulky 1,3-benzothiazole heterocyclic moiety. This assumption was further supported by DFT studies of the optimized geometrical structures of $E-2$ and $Z$-2 as shown in Scheme 1. The calculations were computed by Gaussian 09 software using B3LYP as functional energy and 6$31 \mathrm{G}(\mathrm{d}, \mathrm{p})$ as a basis set, ${ }^{25-28}$ revealed the equal energies of both geometrical isomers (-1532.9 au for $E-2$ and -1533 au for $Z-2)$.

Based on the skeletal features of the key compound 2, we hypothesized the pathway shown in Scheme 2 towards oxocine skeleton. In order to build up this 8-membered heterocycle, our hypothesis was based upon creating a new connectivity between the oxygen pro-nucleophile and cyano electrophilic position. In order to unveil the oxygen nucleophile, the $\gamma$-pyrone ring has to be opened using some nucleophile to generate free hydroxyl group as shown in intermediate $\mathbf{B}$ (Pathway a). After that, the in situ generated hydroxyl group will attack cyano group to give the desired oxocine skeleton. Actually, this process most probably will be accompanied by various side reactions (for example: Pathways b and c) due to the presence of different nucleophiles which can easily attack the cyano group as well.

In order to test the possibility of our hypothesis, we selected the reaction of chromonylidene benzothiazol-2-ylacetonitrile 2 with

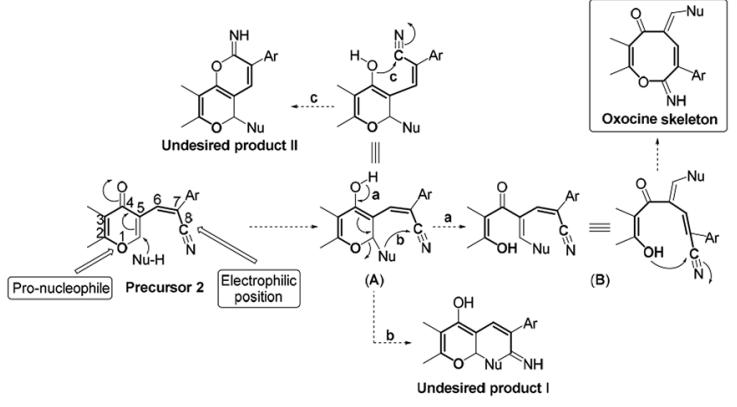

Scheme 2 Working hypothesis. hydroxylamine hydrochloride to build up the oxocinol heterocycle 3a (Table 1). However, no reaction was observed by boiling 2 with hydroxylamine hydrochloride in ethanol (Entry 1), trace amount of the desired product 3a was detected by performing the reaction in 1,4-dioxane at $80{ }^{\circ} \mathrm{C}$ (Entry 2). By increasing the temperature to $101{ }^{\circ} \mathrm{C}$, the desired product $3 \mathrm{a}$ was isolated in $55 \%$ yield (Entry 3 ). Additionally, the use of other solvents with increasing boiling points failed to improve the yield of 3a (Entries 4-8). The attempts by using different organic and inorganic basic additives failed to increase the chemical yield as well (Entries 9-13). Moreover, the use of basic additives promoted different reaction pathways and leaded to tedious chromatographic purification of 3a (Entries 913). Increasing the amount of hydroxylamine hydrochloride (1.5 equivalent) didn't impart any benefits (Entry 14).

The skeleton of oxocinol 3a was secured based upon different analytical analyses. Firstly, IR spectrum showed absorption peaks at regions $3430-3570,3319$ and $3198 \mathrm{~cm}^{-1}$ assigned for two OH's and NH groups. In addition, ${ }^{1} \mathrm{H}$ NMR spectrum of 3a showed two characteristic singlets at 8.78 and $8.83 \mathrm{ppm}$ which were assigned to protons $\mathrm{CH}=\mathrm{N}$ and $\mathrm{H}-4$ (oxocinol), respectively. The ${ }^{13} \mathrm{C}$ NMR spectrum of 3a exhibited all carbons of the proposed structure. EI-MS supported the proposed structure of compound 3a by the presence of molecular ion peak at $m / z 413$, which was compatible with its molecular weight. The formation of side products 4 (ref. 29) and 5 (ref. 30) was excluded due to the absence of aliphatic $\mathrm{CH}$ in ${ }^{1} \mathrm{H}$ - and ${ }^{13} \mathrm{C}-\mathrm{NMR}$.

Table 1 Optimization of the reaction conditions ${ }^{a}$

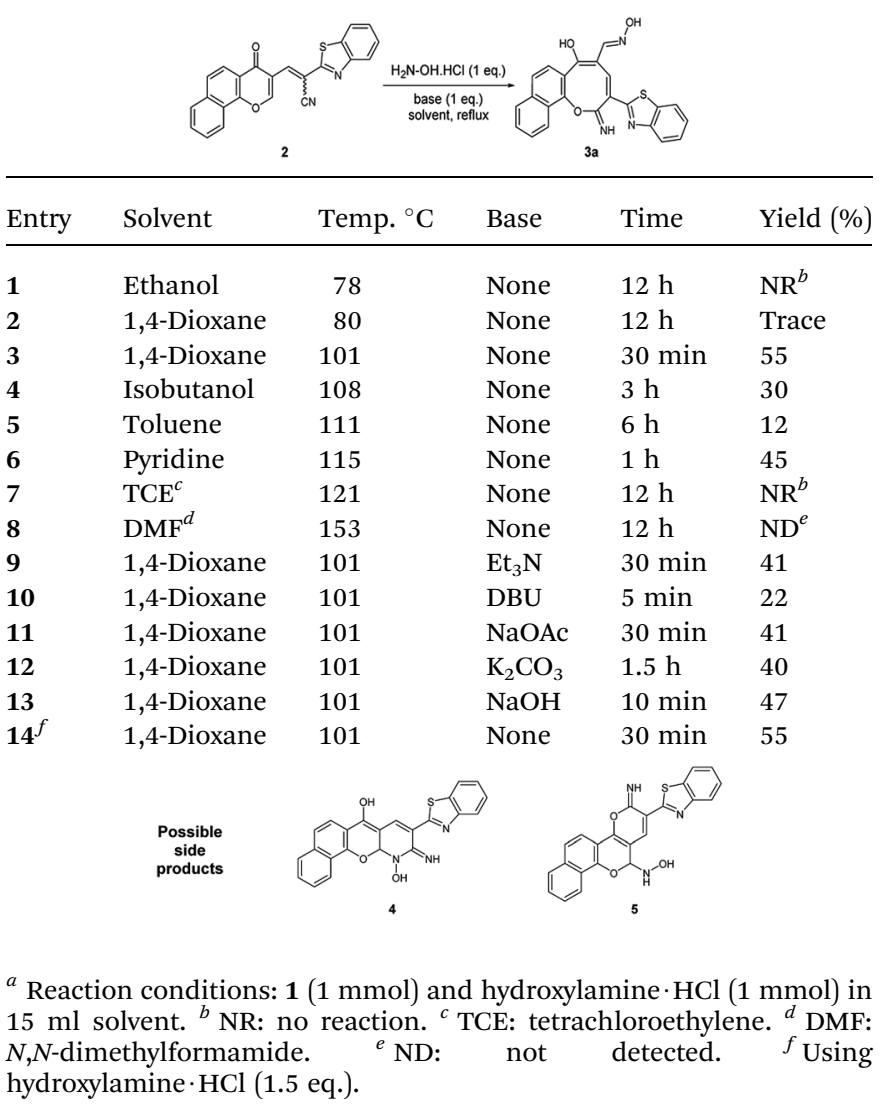




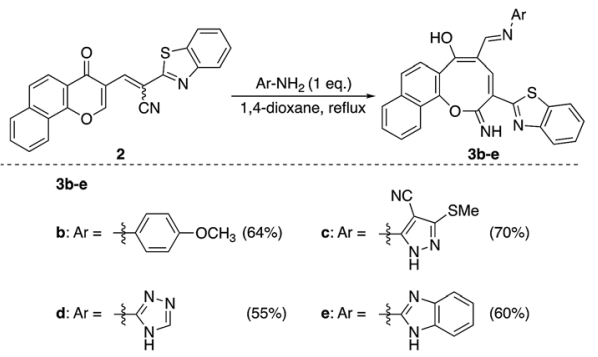

Scheme 3 Reaction of chromonylidene 2 with different $1^{\circ}$ amines.

Similarly, the newly developed methodology could be applied with different primary homo and heteroaryl amines such as $p$-ansidine, 5 -amino-3-methylthio- $1 \mathrm{H}$-pyrazole-4carbonitrile, 2-amino-1,3,4-triazole and 2-amino benzimidazole affording the corresponding oxocinol products $\mathbf{3 b}-\mathbf{e}$ in moderate to good yields (Scheme 3).

Additionally, the reaction of 2 with cyanoacetic acid hydrazide in the presence of a catalytic amount of triethylamine afforded oxocinone 6 in 50\% yield (Scheme 4). This reaction involved initially the aforementioned cascade process to build up the corresponding oxocinol intermediate I which underwent enol to keto tautomerization giving intermediate II, form which the final product $\mathbf{6}$ was formed by further cyclization between hydrazonyl NH and cyano group (Scheme 4). IR spectrum of oxocinone 6 confirmed the absence of cyano group, and instead hydroxyl group was observed at 3550$3420 \mathrm{~cm}^{-1}$ as broad peak in addition to aliphatic $\mathrm{CH}$ functionality peaks at $2961,2898 \mathrm{~cm}^{-1}$. The ${ }^{1} \mathrm{H}$ NMR analysis showed a singlet at $\delta 4.25 \mathrm{ppm}$ assignable to methylene protons of pyrazole ring.

On the other hand, the reaction of chromonylidene 2 with piperidine in refluxing 1,4-dioxane didn't afford the corresponding oxocinol product, and instead, 2-(benzo[d]thiazol-2yl)-12-(piperidin-1-yl)-4,12-dihydro-3H-benzo[7,8]chromeno[4,3$b$ ]pyridine-3-one (7) was obtained in $66 \%$ yield (Scheme 5). The formation of pyridinone 7 was proposed to proceed via nucleophilic attack at C-2 of $\gamma$-pyrone accompanied by the generation hydroxyl group at C-4 (intermediate I), which attack the nearby cyano group giving $\alpha$-iminopyrone intermediate II. By Dimroth rearrangement, $\alpha$-iminopyrone intermediate II was transformed into the corresponding product 7 . The IR spectrum of pyridinone 7 showed a broad peak at $3350-3460 \mathrm{~cm}^{-1}$ which was attributable to $\mathrm{NH}$ group in addition to the amidic carbonyl peak at $1643 \mathrm{~cm}^{-1}$. Additionally, the newly inserted aliphatic carbons of piperidinyl moiety were expressed in IR by the peaks at the range of $2931-2816 \mathrm{~cm}^{-1}$. The ${ }^{1} \mathrm{H}$ NMR spectrum of compounds 7 showed a characteristic singlet $\delta 6.97 \mathrm{ppm}$ assigned to the methine proton (H-5). In a different scenario, no

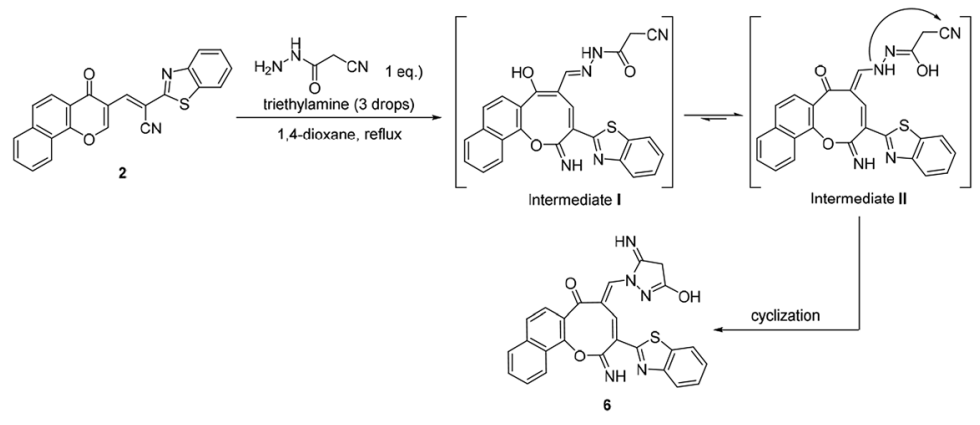

Scheme 4 Reaction of chromonylidene 2 with cyanoacetic acid hydrazide.

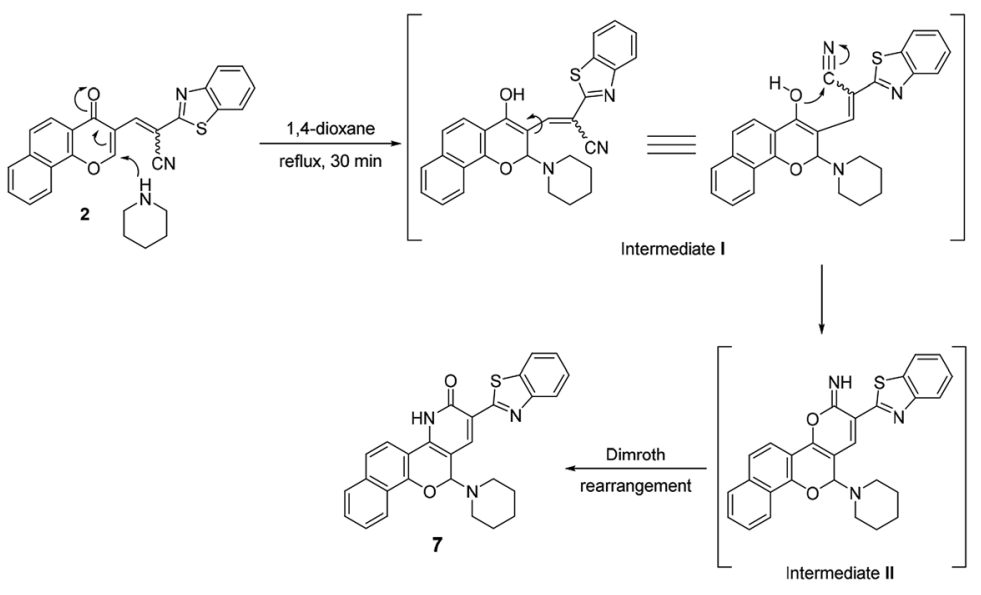

Scheme 5 Reaction of chromonylidene 2 with piperidine. 
reaction was observed in the case of the reaction of chromonylidene 2 with triethylamine ( $3^{\circ}$ amine) even after prolonged reaction time $(12 \mathrm{~h})$.

Moreover, the reaction of chromonylidene 2 with hydrazine hydrate in refluxing 1,4-dioxane afforded product 8 (73\% yield) which was generated in a completely different scenario to the aforementioned reactions with primary and secondary amines (Scheme 6). Treatment of precursor 2 with thiosemicarbazide produced the ring junction nitrogen product 10 in $53 \%$ yield as shown in the reaction pathway (Scheme 7). The reaction proceeded in a similar style to the reaction with hydrazine hydrate (Scheme 6).

The different reaction profiles of chromonylidene 2 with hydroxyl amine and its similar nucleophiles (products 3a-e and 6) compared to hydrazine nucleophile (product 8) were explained on the basis of the electron density on the nucleophilic centers in the corresponding intermediates B (Fig. 2). These electron densities were measured on the optimized structures using Gaussian 09 software at DFT level via B3LYP as energy function and 6-31G $(\mathrm{d}, \mathrm{p})$ as a basis set. ${ }^{25-28}$ In the case of key intermediate for oxocinol 3a, the electron density on phenolic $\mathrm{OH}$ group was found to be $(-0.61 \mathrm{e})$ which is higher than the corresponding density on $\mathrm{NH}$ group $(-0.47 \mathrm{e})$. This significant difference in the electron density value enhanced the nucleophilicity of phenolic $\mathrm{OH}$ compared to that of $\mathrm{NH}$ group leading to the desired oxocine derivatives $3 a-e$ and 6 . In the case of key intermediate for pyridine 8, the electron density on $\mathrm{NH}$ center was increased due to the presence of adjacent $\mathrm{NH}_{2}$ group to value of -0.58 e which became very close to the value of phenolic $\mathrm{OH}$ group. As a result, the 6-membered cyclization (affording product 8) became more energetically favored than 8-membered cyclization (affording product 9). In the case of the reaction with thiosemicarbazide (Scheme 7), the calculated electron densities on the nucleophilic centers could not rationalize solely the formation of product $\mathbf{1 0}$ where its formation might be attributed to some other thermodynamic parameters.

\section{Computational prediction of biological activities of oxocine derivatives 3a-e and 6}

PASS online software was used to predict the putative biological activity spectrum of the oxocine derivatives $3 a-\mathbf{e}$ and 6 which was represented in Table 2 . From the results of biological activity prediction, the synthesized oxocine derivatives 3a-e and 6 showed various anticancer (antimetastatic, antiischemic (cerebral), antineoplastic, and protection from

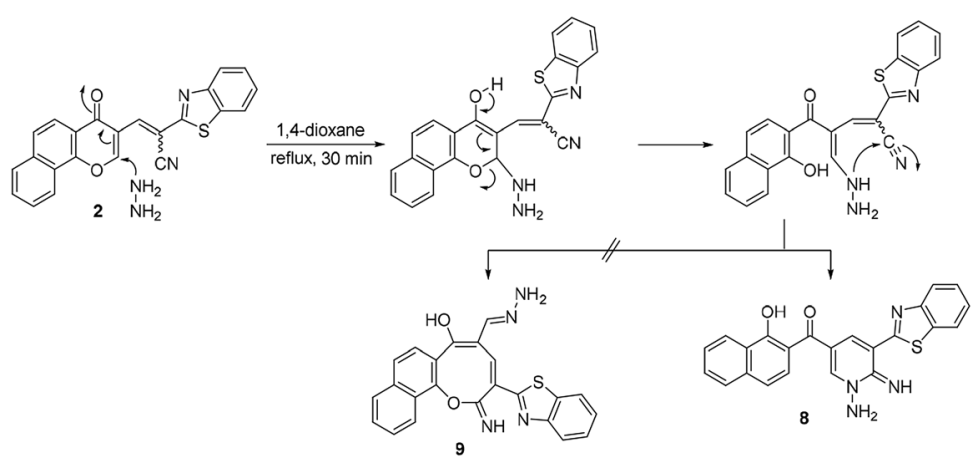

Scheme 6 Reaction of chromonylidene 2 with hydrazine hydrate.

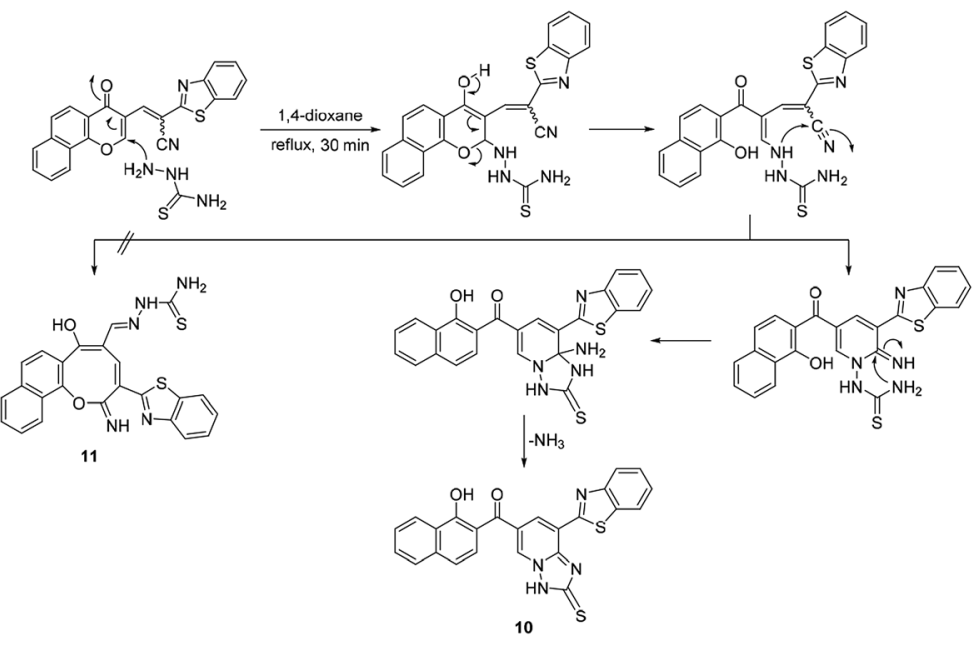

Scheme 7 Reaction of chromonylidene 2 with thiosemicarbazide. 

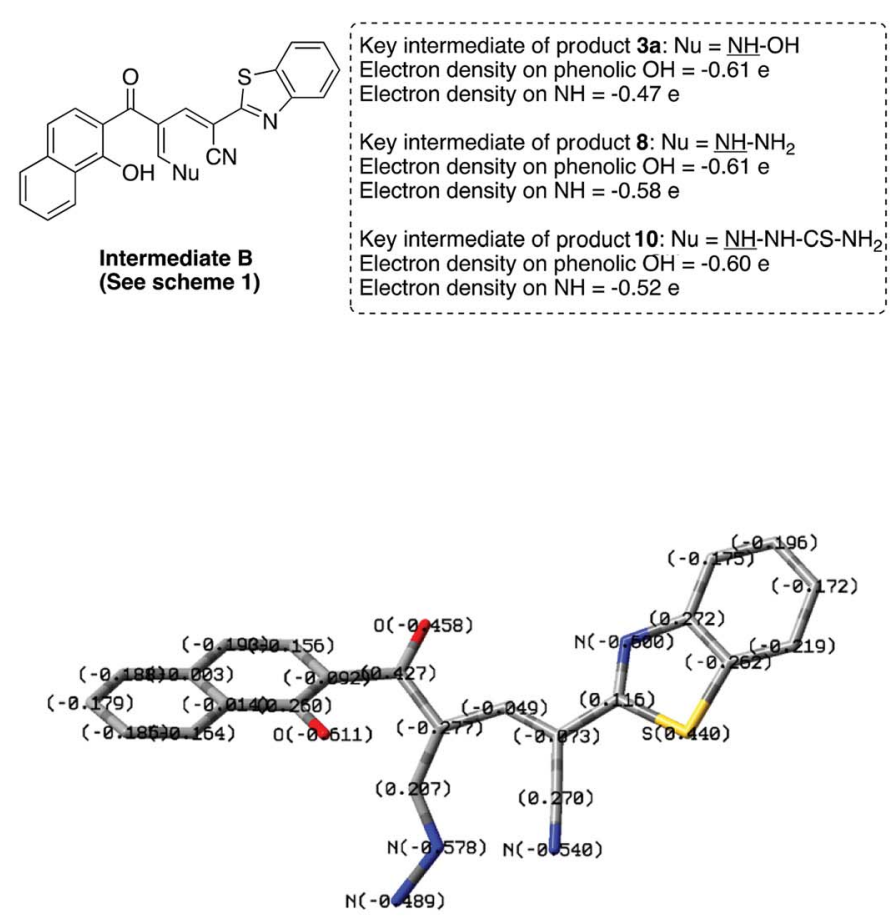

Intermediate $\mathbf{B}$ for product 8

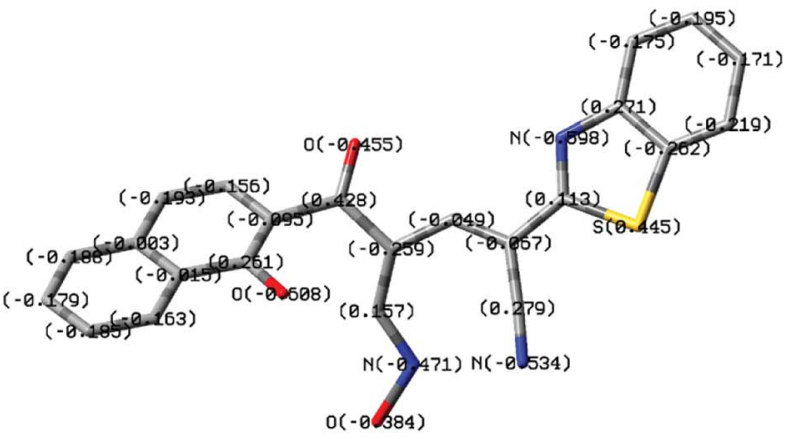

Intermediate $\mathbf{B}$ for product $\mathbf{3 a}$

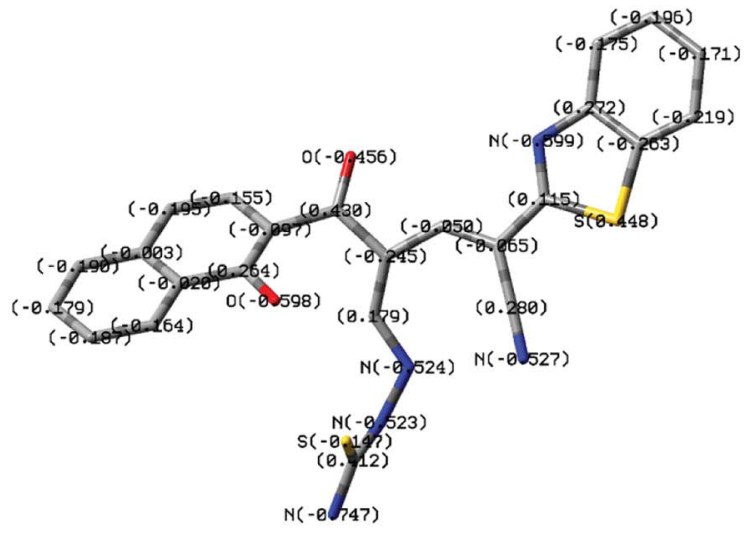

Intermediate $\mathbf{B}$ for product $\mathbf{1 0}$

Fig. 2 Electron densities on $\mathrm{OH}$ and $\mathrm{NH}$ functionalities of the key intermediate $\mathrm{B}$ in case of products $3 \mathrm{a}, 8$ and 10 .

Table 2 Biological activity assessment using PASS online software

\begin{tabular}{|c|c|c|c|c|c|c|c|c|c|c|c|c|c|}
\hline & & \multicolumn{2}{|l|}{$3 \mathbf{a}$} & \multicolumn{2}{|l|}{$3 \mathbf{b}$} & \multicolumn{2}{|l|}{$3 \mathbf{c}$} & \multicolumn{2}{|l|}{ 3d } & \multicolumn{2}{|l|}{$3 e$} & \multicolumn{2}{|l|}{6} \\
\hline \multicolumn{2}{|c|}{ Biological activity } & $\mathrm{Pa}$ & $\mathrm{Pi}$ & $\mathrm{Pa}$ & $\mathrm{Pi}$ & $\mathrm{Pa}$ & $\mathrm{Pi}$ & $\mathrm{Pa}$ & $\mathrm{Pi}$ & $\mathrm{Pa}$ & $\mathrm{Pi}$ & $\mathrm{Pa}$ & $\mathrm{Pi}$ \\
\hline & Antiischemic (cerebral) & 0.472 & 0.125 & 0.378 & 0.204 & NA & NA & 0.414 & 0.174 & NA & NA & 0.503 & 0.104 \\
\hline & Antineoplastic & 0.604 & 0.044 & 0.640 & 0.037 & 0.492 & 0.074 & 0507 & 0.069 & 0.468 & 0.081 & 0.565 & 0.053 \\
\hline & Antineoplastic (brain cancer) & NA & NA & 0.226 & 0.084 & 0.198 & 0.133 & 0212 & 0.108 & 0.202 & 0.126 & NA & NA \\
\hline \multirow{2}{*}{ Antimicrobial } & Antibiotic & 0.183 & 0.033 & 0.254 & 0.019 & 0.147 & 0.051 & 0.181 & 0.034 & 0.176 & 0.036 & 0.169 & 0.039 \\
\hline & Antibacterial & 0.358 & 0.041 & 0.487 & 0.018 & 0.258 & 0.079 & 0.359 & 0.041 & 0.306 & 0.058 & 0.275 & 0.070 \\
\hline
\end{tabular}

prostate cancer), antiviral, and antimicrobial promising activities. Oxocinols $\mathbf{3 a}$ and $\mathbf{3 b}$ showed the best probable activity in the treatment of cancer. In addition, oxocinol $\mathbf{3 b}$ revealed the best predicted antimicrobial activity. Ultimately, compounds 3d and 3e may possess antiviral (influenza A) activity.

\section{Applications of oxocine derivatives $3 a-e$ and 6 in dye- sensitized solar cells (DSSCs)}

DFT calculations followed by TD-DFT studies were performed for oxocine derivatives 3a-e and 6 using B3LYP as energy function and 6-31G $(\mathrm{d}, \mathrm{p})^{25-28}$ as a basis set to investigate their theoretical GSOP/ESOP energy levels (Fig. 3) and their optical absorption spectra (Fig. 4). ${ }^{31}$

In addition, from the results displayed in Table 3 , it is quite interesting to note that, all products $3 \mathbf{a}-\mathbf{e}$ and 6 possess the thermodynamic requirements as an application for DSSCs. $^{32,33}$ The estimated ESOP levels of $\mathbf{3 a - e}$ and 6 were found to be $3 \mathbf{a}(-3.13 \mathrm{eV}), 3 \mathbf{b}(-2.66 \mathrm{eV}), 3 \mathbf{c}(-2.76 \mathrm{eV}), \mathbf{3 d}$ $(-3.12 \mathrm{eV}), 3 \mathrm{e}(-2.41 \mathrm{eV})$ and $6(-3.02 \mathrm{eV})$. These values are more positive than the conduction band (CB) potential of $\mathrm{TiO}_{2}(-4.2 \mathrm{eV})$; showing that their ability for the electron injection. Furthermore, the calculated GSOP/HOMO levels of 


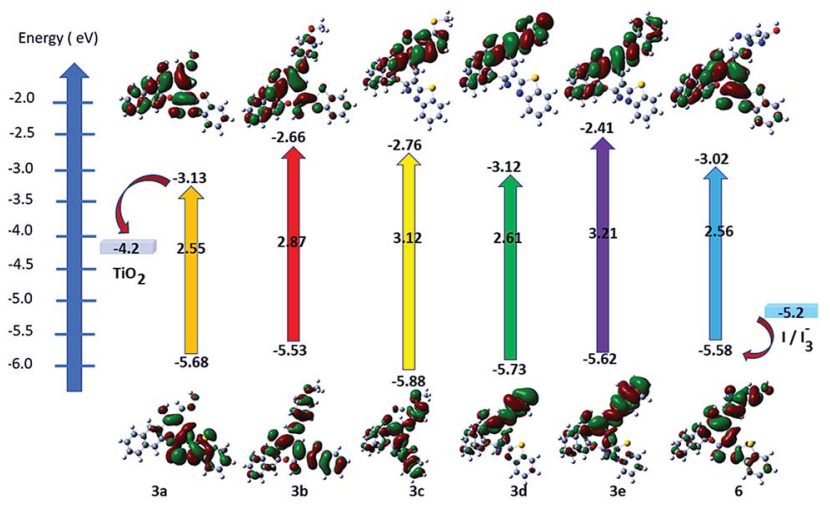

Fig. 3 Energy level diagram of oxocine derivatives $3 a-e$ and 6 .

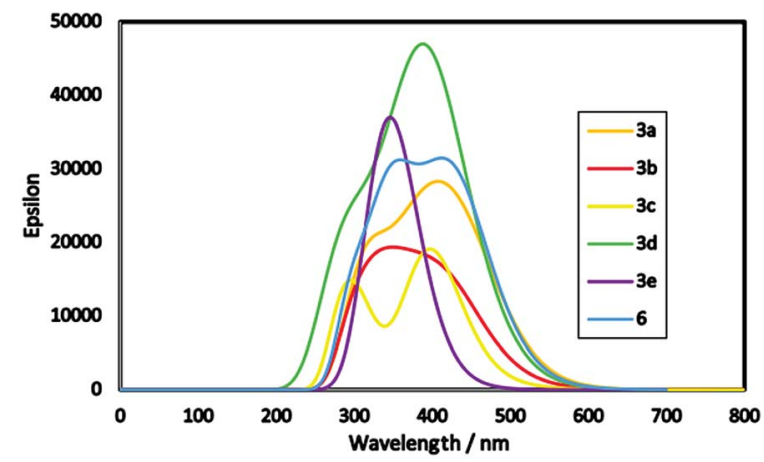

Fig. 4 Simulated absorption spectra of oxocine derivatives $3 a-e$ and 6 .

Table 3 Calculated $E_{0-0}$, GSOP and ESOP for oxocine derivatives $3 a-e$ and 6

\begin{tabular}{lllll}
\hline Product & Basis set & GSOP $(\mathrm{eV})$ & $E_{0-0}$ & ESOP $(\mathrm{eV})$ \\
\hline 3a & B3LYP/6-31G (d,p) & -5.68 & 2.55 & -3.13 \\
3b & & -5.53 & 2.87 & -2.66 \\
3c & & -5.88 & 3.12 & -2.76 \\
3d & & -5.73 & 2.61 & -3.12 \\
3e & & -5.62 & 3.21 & -2.41 \\
6 & & -5.58 & 2.56 & -3.02 \\
\hline
\end{tabular}

3a $(-5.68 \mathrm{eV}), 3 \mathbf{b}(-5.53 \mathrm{eV}), 3 \mathbf{c}(-5.88 \mathrm{eV}), 3 \mathrm{~d}(-5.73 \mathrm{eV}), 3 \mathbf{e}$ $(-5.62 \mathrm{eV})$ and $6(-5.68 \mathrm{eV})$ were found to be more negative than the oxidation potential of the electrolyte $(-5.2 \mathrm{eV})\left(\mathrm{I}_{3}{ }^{-}\right.$/ $\left.\mathrm{I}^{-}\right)$, exhibited the regeneration of the electrons.

Furthermore, energy band gap $\left(E_{0-0}\right)$ can be estimated from the onset of the lowest energy peak. ${ }^{34}$ Small band gap increases the optical properties of the products allowing for absorption most of the incident light. From Fig. 4, product 3a is found to be red shifted than other products which attributed to its lowest optical energy gap of $2.55 \mathrm{eV}$. Moreover, molar extinction coefficient (epsilon) plays a vital role for enhancing the light harvesting ability of the dye where its higher value indicates maximum light harvesting capability. For example, product 3d showed the highest molar extinction co-efficient with broadening in its absorption peak depending on the nature of its donor and acceptor structures, and as a result it is expected to show improved photovoltaic performance in DSSCs. ${ }^{35}$

\section{Conclusion}

A promising protocol for the synthesis of oxocine derivatives 3a-e and $\mathbf{6}$ has been developed via reaction of chromonylidene 2 with different $\mathrm{NH}_{2}$ bearing nucleophiles under metal free conditions refluxing in 1,4-dioxane. Other nucleophiles such as piperidine, hydrazine and thiosemicarbazide failed to give the desired oxocine derivatives and instead, they afforded different pyridine derivatives 7, 8 and 10. Some oxocine products showed some promising probability of biological activity in the treatment of cancer, influenza A, and as antimicrobial agents. Furthermore, TD-DFT simulated spectra and calculated GSOP/ESOP energy levels indicated the ability of using products 3a-e and $\mathbf{6}$ in the application of DSSCs. The present study is just preliminary where detailed studies for the synthesis of different oxocine derivatives in addition to biological activity and DSSCs applications are currently underway, with collaboration with different specialized research groups, and will be reported in the due time.

\section{Experimental}

\section{General}

The melting points of the newly synthesized compounds were measured on a Gallenkamp electrical melting point apparatus using open glass capillaries and are reported in degree Celsius $\left({ }^{\circ} \mathrm{C}\right)$ (uncorrected). The infrared spectra (IR) were determined using the pressed $\mathrm{KBr}$ disc method on a Mattson 5000 FT-IR spectrophotometer (Faculty of Pharmacy, Mansoura University) or Nicolet iS10 FT-IR Spectrometer (Faculty of Science, Mansoura University). The ${ }^{1} \mathrm{H}$-NMR spectra were measured on Bruker AC $300 \mathrm{MHz}$ (Faculty of Science, Cairo University), Bruker Avance III $400 \mathrm{MHz}$ (Faculty of Pharmacy, Beni Suef University) and/or JEOL ECA II $500 \mathrm{MHz}$ (Faculty of Science, Mansoura University) using tetramethylsilane (TMS) as an internal reference, and using DMSO- $d_{6}$ or trifluoroacetic acid (TFA) as solvents. The signals' multiplicities are reported as follows: $\mathrm{s}=$ singlet, $\mathrm{d}=$ doublet, $\mathrm{dd}=$ doublet of doublets and $\mathrm{m}=$ multiplet. Exchangeable protons were detected through $\mathrm{D}_{2} \mathrm{O}$ test. ${ }^{13} \mathrm{C}$-NMR spectra were measured on JEOL ECA II $125 \mathrm{MHz}$ (Faculty of Science, Mansoura University). The electron impact mass spectra (EI-MS) were determined on Thermo Fisher scientific DSQ II GC/MS with focus GC (70 eV) (Faculty of Science, Mansoura University) or Kratos MS (70 eV) equipment (Faculty of Pharmacy, Al-Azhar University). Elemental analysis was executed at the microanalytical lab at Cairo University. All reactions were monitored using thin layer chromatography (TLC) on aluminum sheets pre-coated with $\mathrm{Al}_{2} \mathrm{O}_{3}$ with fluorescent indicator F254, Merck (Darmstadt, Germany). DFT-followed by TD-DFT were performed using Gaussian 09 package software. The simulated absorption spectra of products 3a-e and 6 obtained at B3LYP/6-31G (d,p) level. 


\section{Synthesis}

Synthesis of 2-(benzo[d]thiazol-2-yl)-3-(4-oxo-4H-benzo[ $[h]$ chromen-3-yl)acrylonitrile (2).

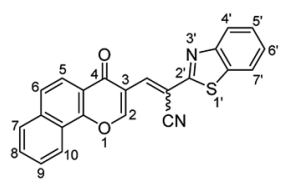

A mixture of 3-formylbenzochromone ( $673 \mathrm{mg}, 3 \mathrm{mmol}$ ), 2benzothiazoleacetonitrile $(523 \mathrm{mg}, 3 \mathrm{mmol})$ in glacial acetic acid $(25 \mathrm{ml})$ was refluxed for $20 \mathrm{~min}$. The formed precipitate was filtered off and recrystallized from a mixture of DMF/EtOH giving product $2(E: Z=1: 1)$. Yield (1027 $\mathrm{mg}, 90 \%)$; reddish orange crystals; $\mathrm{mp}=286-288^{\circ} \mathrm{C}$; IR $\left(\mathrm{KBr}, \nu / \mathrm{cm}^{-1}\right): 3061$ (aromatic $\mathrm{CH}$ ), $2206(\mathrm{CN}), 1650(\mathrm{C}=\mathrm{O}), 1603(\mathrm{C}=\mathrm{N})$; ${ }^{1} \mathrm{H}$ NMR (500 MHz, DMSO$\left.d_{6}\right): \delta(\mathrm{ppm}) 7.40\left(\mathrm{~s}, 1 \mathrm{H}, \mathrm{H}-2_{\mathrm{a}}\right), 7.52\left(\mathrm{dd}, 1 \mathrm{H}, \mathrm{H}-6_{\mathrm{a}}^{\prime}, J=7.00,8.00\right.$ $\mathrm{Hz}), 7.55\left(\mathrm{~d}, 1 \mathrm{H}, \mathrm{H}_{-}^{\prime}\right.$ a $\left.J=8.20 \mathrm{~Hz}\right), 7.60-7.67(\mathrm{~m}, 4 \mathrm{H}, \mathrm{Ar}-\mathrm{H}), 7.73$ (dd, $1 \mathrm{H}, \mathrm{H}-6_{\mathrm{b}}^{\prime}, J=7.50,8.00 \mathrm{~Hz}$ ),7.85-7.91 (m, 3H, Ar-H), 7.93 (d, $\left.1 \mathrm{H}, \mathrm{H}-7_{\mathrm{b}}^{\prime}, J=8.20 \mathrm{~Hz}\right), 8.00(\mathrm{~d}, 2 \mathrm{H}, \mathrm{Ar}-\mathrm{H}, J=8.90 \mathrm{~Hz}), 8.04(\mathrm{~s}, 1 \mathrm{H}$, $\mathrm{H}-2_{\mathrm{b}}$ ),8.05 (d, $\left.1 \mathrm{H}, \mathrm{Ar}-\mathrm{H}, J=8.90 \mathrm{~Hz}\right), 8.10-8.18(\mathrm{~m}, 4 \mathrm{H}, \mathrm{Ar}-\mathrm{H})$, $8.22\left(\mathrm{~d}, 1 \mathrm{H}, \mathrm{H}-10_{\mathrm{a}}, J=7.60 \mathrm{~Hz}\right), 8.35\left(\mathrm{~s}, 1 \mathrm{H}, \mathrm{CH}_{\mathrm{a}}=\mathrm{C}-\mathrm{CN}\right), 8.57$ (d, $\left.1 \mathrm{H}, \mathrm{H}-10_{\mathrm{b}}, J=7.60 \mathrm{~Hz}\right), 9.46\left(\mathrm{~s}, 1 \mathrm{H}, \mathrm{CH}_{\mathrm{b}}=\mathrm{C}-\mathrm{CN}\right) ; \mathrm{EI}-\mathrm{MS} m / z(\%)$ : $382.14\left[\mathrm{M}^{+}+2\right]$ (11.91), $381.19\left[\mathrm{M}^{+}+1\right]$ (29.07), $380.20\left[\mathrm{M}^{+}\right]$ (100.00), 352.22 (30.16), 351.19 (94.43), 350.30 (11.86), 114.12 (26.95); anal. calcd for $\mathrm{C}_{23} \mathrm{H}_{12} \mathrm{~N}_{2} \mathrm{O}_{2} \mathrm{~S}$ (380.06): C, 72.62; H, 3.18; N, 7.36 ; S, 8.43\%. Found: C, 72.65; H, 3.20; N, 7.32; S, 8.50\%.

General procedure for the synthesis of compounds 3a-e, 6-8 and 10. A suspension of compound 2 (380 $\mathrm{mg}, 1 \mathrm{mmol})$ and nitrogen nucleophilic component $(1 \mathrm{mmol})$ such as [hydroxylamine $\cdot \mathrm{HCl}, p$-anisidine, 5-amino-3-(methylthio)- $1 H$-pyrazole3-carbonitrile, 2-amino-1,3,4-triazole, 2-aminobenzimidazole, cyanoacetic acid hydrazide, piperidine, hydrazine hydrate, thiosemicarbazide] in $15 \mathrm{ml}$ dry 1,4-dioxane was refluxed for $30 \mathrm{~min}$ (in the case of cyanoacetic acid hydrazide, 3 drops of $\mathrm{Et}_{3} \mathrm{~N}$ was added as catalyst). The formed precipitate was filtered off, washed several times with hot 1,4-dioxane followed by absolute EtOH to give the corresponding products without the need for further purification.

3-(Benzo[ $[d]$ thiazol-2-yl)-6-hydroxy-2-imino-2H-naphtho[1,2b] oxocine-5-carbaldehyde oxime (3a).

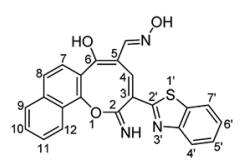

Yellow needles; (227 mg, 55\%); mp > $330{ }^{\circ} \mathrm{C}$; IR ( $\mathrm{KBr}, \nu /$ $\mathrm{cm}^{-1}$ ): 3430-3570 (OH, broad), $3319(\mathrm{NH}), 3065$ (aromatic $\mathrm{CH}), 1627(\mathrm{C}=\mathrm{N}), 1583(\mathrm{C}=\mathrm{C}) ;{ }^{1} \mathrm{H}$ NMR (500 MHz, TFA): $\delta(\mathrm{ppm}) 7.45(\mathrm{~d}, 1 \mathrm{H}, \mathrm{H}-8, J=8.70 \mathrm{~Hz}), 7.51$ (d, $1 \mathrm{H}, \mathrm{H}-7, J=8.90$ $\mathrm{Hz}$ ), 7.66-7.72 (m, 2H, Ar-H), 7.75-7.82 (m, 2H, Ar-H), 7.87 (d, $1 \mathrm{H}, \mathrm{H}-7^{\prime}, J=8.00 \mathrm{~Hz}$ ), 8.09 (d, $\left.1 \mathrm{H}, \mathrm{H}-4^{\prime}, J=8.00 \mathrm{~Hz}\right), 8.22(\mathrm{~d}, 1 \mathrm{H}$, $\mathrm{H}-9, J=8.00 \mathrm{~Hz}), 8.56(\mathrm{~d}, 1 \mathrm{H}, \mathrm{H}-12, J=8.50 \mathrm{~Hz}), 8.78(\mathrm{~s}, 1 \mathrm{H}$, $\mathrm{CH}=\mathrm{N}), 8.83$ (s, 1H, H-4); ${ }^{13} \mathrm{C}$ NMR (126 MHz, TFA): $\delta$ (ppm) 119.10, 122.29, 123.51, 124.72, 125.06, 125.95, 126.11, 126.74, 128.99, 129.68, 130.01, 130.06, 133.99, 135.35, 140.41, 140.85,
141.76, 152.60, 153.17, 153.21, 163.29, 166.97, 194.84; EI-MS m/z (\%): $415.18\left[\mathrm{M}^{+}+2\right]$ (5.69), $414.26\left[\mathrm{M}^{+}+1\right](23.88), 413.22\left[\mathrm{M}^{+}\right]$ (85.42), 397.24 (100.00), 396.25 (41.78), 381.21 (25.85), 368.18 (7.77); anal. calcd for $\mathrm{C}_{23} \mathrm{H}_{15} \mathrm{~N}_{3} \mathrm{O}_{3} \mathrm{~S}$ (413.45): C, 66.82; $\mathrm{H}, 3.66 ; \mathrm{N}$, 10.16; S, 7.75\%. Found: C, 66.80; H, 3.69; N, 10.12; S, 7.79\%.

3-(Benzo $[d]$ thiazol-2-yl)-2-imino-5-((4-methoxyphenyl)imino) methyl-2H-naphtho[1,2-b] oxocin-6-ol (3b).

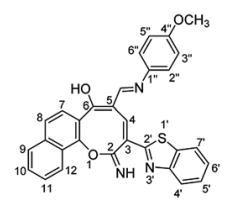

Yellowish orange crystals; (322 mg, 64\%); mp 194-196 ${ }^{\circ} \mathrm{C}$; IR $\left(\mathrm{KBr}, \nu / \mathrm{cm}^{-1}\right)$ : 3300-3450 ( $\mathrm{OH}, \mathrm{NH}$, broad), 3065 (aromatic $\left.\mathrm{CH}\right)$, 2917 (aliphatic $\mathrm{CH}), 1630(\mathrm{C}=\mathrm{N}), 1608(\mathrm{C}=\mathrm{C}) ;{ }^{1} \mathrm{H}$ NMR (500 MHz, DMSO- $\left.d_{6}\right): \delta$ (ppm) 3.77 (s, 3H, $\left.\mathrm{OCH}_{3}\right), 7.00$ (dd, $2 \mathrm{H}, \mathrm{H}-3^{\prime \prime}$, $\mathrm{H}-5^{\prime \prime}, J=2.10,6.90, \mathrm{~Hz}$ ), 7.48 (d, 1H, H-8, $J=8.90 \mathrm{~Hz}$ ), 7.53 (dd, $1 \mathrm{H}, \mathrm{Ar}-\mathrm{H}, J=7.00,7.50 \mathrm{~Hz}), 7.59-7.64(\mathrm{~m}, 2 \mathrm{H}, \mathrm{Ar}-\mathrm{H}), 7.70(\mathrm{~d}, 1 \mathrm{H}$, $\mathrm{H}-7, J=8.90 \mathrm{~Hz}$ ), 7.73 (dd, $1 \mathrm{H}, \mathrm{Ar}-\mathrm{H}, J=1.50,8.00 \mathrm{~Hz}$ ), 7.78 (dd, $\left.2 \mathrm{H}, \mathrm{H}-2^{\prime \prime}, \mathrm{H}-6^{\prime \prime}, J=2.10,6.90 \mathrm{~Hz}\right), 7.96\left(\mathrm{~d}, 1 \mathrm{H},{\mathrm{H}-7^{\prime}}^{\prime} J=8.20 \mathrm{~Hz}\right.$ ), 8.19 (d, $\left.1 \mathrm{H}, \mathrm{H}-4^{\prime}, J=7.60 \mathrm{~Hz}\right), 8.26$ (d, $\left.1 \mathrm{H}, \mathrm{H}-9, J=8.20 \mathrm{~Hz}\right), 8.38$ $(\mathrm{d}, 1 \mathrm{H}, \mathrm{H}-12, J=8.20 \mathrm{~Hz}), 8.51(\mathrm{~d}, 1 \mathrm{H}, \mathrm{CH}=\mathrm{N}, J=2.10 \mathrm{~Hz}), 8.69$ (d, $1 \mathrm{H}, \mathrm{H}-4, J=2.10 \mathrm{~Hz}), 11.89$ (s, 1H, NH or OH), 12.96 (s, 1H, $\mathrm{NH}$ or $\mathrm{OH}$ ); anal. calcd for $\mathrm{C}_{30} \mathrm{H}_{21} \mathrm{~N}_{3} \mathrm{O}_{3} \mathrm{~S}$ (503.13): C, 71.55; $\mathrm{H}$, 4.20 ; N, 8.34; S, 6.37\%. Found: C, 71.59; H, 4.18; N, 8.33; S, 6.36\%.

5-(((3-(benzo[ $d]$ thiazol-2-yl)-6-hydroxy-2-imino-2H-naphtho [1,2-b]oxocin-5-yl)methylene)amino)-3-(methylthio)-1Hpyrazole-4-carbonitrile (3c).

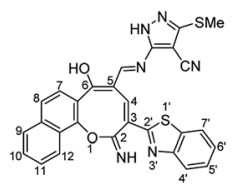

Yellowish orange crystals; (374 mg, 70\%); mp 326-327 ${ }^{\circ} \mathrm{C}$; IR $\left(\mathrm{KBr}, \nu / \mathrm{cm}^{-1}\right)$ : 3380-3550 (OH, broad), $3450(\mathrm{NH}), 3226(\mathrm{NH})$, $2215(\mathrm{CN}), 1630(\mathrm{C}=\mathrm{N}), 1600(\mathrm{C}=\mathrm{C}) ;{ }^{1} \mathrm{H}$ NMR $(500 \mathrm{MHz}$, DMSO- $\left.d_{6}\right): \delta(\mathrm{ppm}) 2.60\left(\mathrm{~s}, 3 \mathrm{H}, \mathrm{SCH}_{3}\right), 7.49-7.78(\mathrm{~m}, 6 \mathrm{H}, \mathrm{Ar}-\mathrm{H})$, $7.96(\mathrm{~d}, 1 \mathrm{H}, \mathrm{Ar}-\mathrm{H}, J=8.00 \mathrm{~Hz}), 8.15$ (d, $1 \mathrm{H}, \mathrm{Ar}-\mathrm{H}, J=8.50 \mathrm{~Hz}$ ), $8.22(\mathrm{~d}, 1 \mathrm{H}, \mathrm{Ar}-\mathrm{H}, J=8.00 \mathrm{~Hz}), 8.41(\mathrm{~d}, 1 \mathrm{H}, \mathrm{Ar}-\mathrm{H}, J=8.50 \mathrm{~Hz}$ ), $8.63(\mathrm{~d}, 1 \mathrm{H}, \mathrm{Ar}-\mathrm{H}, J=2.50 \mathrm{~Hz}), 8.76(\mathrm{~d}, 1 \mathrm{H}, \mathrm{Ar}-\mathrm{H}, J=2.50 \mathrm{~Hz}$ ), 9.49 (s, 1H, NH or OH), $10.00(\mathrm{~s}, 1 \mathrm{H}, \mathrm{NH}$ or $\mathrm{OH}), 12.78(\mathrm{~s}, 1 \mathrm{H}$, $\mathrm{NH}$ or $\mathrm{OH})$; EI-MS $m / z$ (\%): $534.82\left[\mathrm{M}^{+}\right]$(48.94), 507.08 (40.21), 502.40 (32.33), 473.18 (16.44), 271.20 (54.74), 243.06 (68.660), 183.42 (77.08), 180.05 (100.00), 129.09 (58.57), 81.14 (58.28); anal. calcd for $\mathrm{C}_{28} \mathrm{H}_{18} \mathrm{~N}_{6} \mathrm{O}_{2} \mathrm{~S}_{2}$ (534.09): C, 62.91; H, 3.39; N, 15.72; S, 11.99\%. Found: C, 62.95; H, 3.35; N, 15.73; S, 11.96\%.

5-(((4H-1,2,4-triazol-3-yl)imino)methyl)-3-(benzo[ $d]$ thiazol-2yl)-2-imino-2H-naphtho[1, 2-b]oxocin-6-ol (3d).

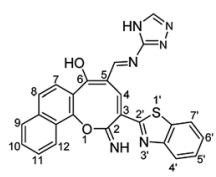


Canary yellow crystals; ( $255 \mathrm{mg}, 55 \%) ; \mathrm{mp}>330{ }^{\circ} \mathrm{C}$; IR $(\mathrm{KBr}$, $\left.\nu / \mathrm{cm}^{-1}\right):$ 3200-3450 (OH, broad), $3424(\mathrm{NH}), 3209(\mathrm{NH}), 3059$ (aromatic $\mathrm{CH}), 1601(\mathrm{C}=\mathrm{N}), 1550(\mathrm{C}=\mathrm{C}) ;{ }^{1} \mathrm{H}$ NMR $(500 \mathrm{MHz}$, DMSO- $\left.d_{6}\right): \delta(\mathrm{ppm}) 7.48(\mathrm{~d}, 1 \mathrm{H}, \mathrm{H}-8, J=8.90 \mathrm{~Hz}), 7.54(\mathrm{dd}, 1 \mathrm{H}$, $\mathrm{Ar}-\mathrm{H}, J=7.49,7.51 \mathrm{~Hz}$ ), 7.62 (dd, $2 \mathrm{H}, \mathrm{Ar}-\mathrm{H}, J=6.50,8.50 \mathrm{~Hz}$ ), $7.66(\mathrm{~d}, 1 \mathrm{H}, \mathrm{H}-7, J=8.90 \mathrm{~Hz}), 7.72(\mathrm{dd}, 1 \mathrm{H}, \mathrm{Ar}-\mathrm{H}, J=7.00,8.00$ $\mathrm{Hz}), 7.82(\mathrm{~s}, 1 \mathrm{H}$, triazole), $7.95(\mathrm{~d}, 1 \mathrm{H}, \mathrm{H}-9, J=8.20 \mathrm{~Hz}), 8.16(\mathrm{~d}$, $1 \mathrm{H}, \mathrm{H}-7^{\prime}, J=7.60 \mathrm{~Hz}$ ), 8.21 (d, $\left.1 \mathrm{H}, \mathrm{H}-4^{\prime}, J=7.60 \mathrm{~Hz}\right), 8.38(\mathrm{~d}, 1 \mathrm{H}$, $\mathrm{H}-12, J=8.20 \mathrm{~Hz}), 8.61(\mathrm{~s}, 1 \mathrm{H}, \mathrm{CH}=\mathrm{N}), 8.75(\mathrm{~s}, 1 \mathrm{H}, \mathrm{H}-4), 12.51$ (s, $1 \mathrm{H}, \mathrm{NH}$ or $\mathrm{OH}), 12.77$ (s, 1H, NH or OH), $13.76(\mathrm{~s}, 1 \mathrm{H}, \mathrm{NH}$ or

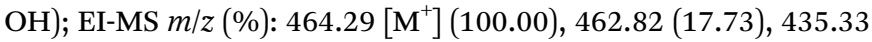
(13.86), 380.18 (13.32), 379.22 (9.70), 306.23 (18.92), 115.18 (17.33); anal. calcd for $\mathrm{C}_{25} \mathrm{H}_{16} \mathrm{~N}_{6} \mathrm{O}_{2} \mathrm{~S}$ (464.11): C, 64.64; $\mathrm{H}$, 3.47; N, 18.09; S, 6.90\%. Found: C, 64.66; H, 3.42; N, 18.03; S, $7.01 \%$.

5-(((1H-benzo[d]imidazol-2-yl)imino)methyl)-3-(benzo $[d]$ thiazol-2-yl)-2-imino-2H-naph-tho[1,2-b]oxocin-6-ol (3e).

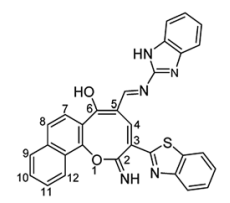

Yellow needles; (308 mg, 60\%); mp $318^{\circ} \mathrm{C}$; IR $\left(\mathrm{KBr}, \nu / \mathrm{cm}^{-1}\right)$ : 3270-3420 (OH, NH, broad), $3347(\mathrm{NH}), 3058$ (aromatic $\mathrm{CH}$ ), $1631(\mathrm{C}=\mathrm{N}), 1590(\mathrm{C}=\mathrm{C}) ;{ }^{1} \mathrm{H}$ NMR $\left(400 \mathrm{MHz}, \mathrm{DMSO}-d_{6}\right)$ : $\delta(\mathrm{ppm})$ 7.22-7.56 (m, 7H, Ar-H), $7.67(\mathrm{dd}, 1 \mathrm{H}, \mathrm{Ar}-\mathrm{H}, J=8.00$, $8.50 \mathrm{~Hz}), 7.77$ (d, $2 \mathrm{H}, \mathrm{Ar}-\mathrm{H}, J=8.00 \mathrm{~Hz}), 8.01$ (d, 1H, H-9, $J=$ $8.00 \mathrm{~Hz}$ ), $8.08(\mathrm{dd}, 2 \mathrm{H}, \mathrm{Ar}-\mathrm{H}, J=8.00,8.50 \mathrm{~Hz}), 8.43(\mathrm{~d}, 1 \mathrm{H}, \mathrm{H}-$ $12, J=8.00 \mathrm{~Hz}), 8.85(\mathrm{~s}, 1 \mathrm{H}, \mathrm{CH}=\mathrm{N}), 9.18(\mathrm{~s}, 1 \mathrm{H}, \mathrm{H}-4), 12.01(\mathrm{~s}$, $1 \mathrm{H}, \mathrm{NH}$ or $\mathrm{OH}), 12.53(\mathrm{~s}, 1 \mathrm{H}, \mathrm{NH}$ or $\mathrm{OH}), 13.00(\mathrm{~s}, 1 \mathrm{H}, \mathrm{NH}$ or $\mathrm{OH})$; EI-MS $m / z$ (\%): $515.92\left[\mathrm{M}^{+}+2\right](0.95), 514.32\left[\mathrm{M}^{+}+1\right](1.03)$, $513.61\left[\mathrm{M}^{+}\right]$(2.44), 398.31 (14.90), 397.25 (20.37), 355.34 (13.15), 354.30 (16.10), 337.26 (21.39), 339.26 (48.12), 337.26 (16.73), 40.20 (100.00); anal. calcd for $\mathrm{C}_{30} \mathrm{H}_{19} \mathrm{~N}_{5} \mathrm{O}_{2} \mathrm{~S}$ (513.58): C, 70.16; $\mathrm{H}$, 3.73 ; N, 13.64; S, 6.24\%. Found: C, 70.18; H, 3.70; N, 13.62; S, $6.21 \%$.

3-(benzo[d]thiazol-2-yl)-5-((3-hydroxy-5-imino-4,5-dihydro$1 H$-pyrazol-1-yl)methylene)-2-imino-2,5-dihydro- $6 \mathrm{H}$-naphtho $[1,2-b]$ oxocin-6-one(6).

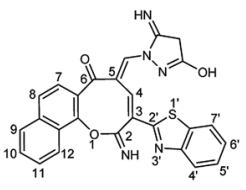

Yellow crystals; ( $240 \mathrm{mg}, 50 \%) ; \mathrm{mp} 310-311^{\circ} \mathrm{C}$; IR (KBr, $\nu /$ $\left.\mathrm{cm}^{-1}\right)$ : 3550-3420 (OH, broad), $3378(\mathrm{NH}), 3209(\mathrm{NH}), 3051$ (aromatic CH), 2961, 2898 (aliphatic CH), $1636(\mathrm{C}=\mathrm{O}), 1600$ $(\mathrm{C}=\mathrm{N}), 1596(\mathrm{C}=\mathrm{C}) ;{ }^{1} \mathrm{H}$ NMR $(500 \mathrm{MHz}, \mathrm{TFA}): \delta(\mathrm{ppm}) 4.25(\mathrm{~s}$, $\left.2 \mathrm{H}, \mathrm{CH}_{2}\right), 7.43(\mathrm{~d}, 1 \mathrm{H}, \mathrm{H}-8, J=8.90 \mathrm{~Hz}), 7.50(\mathrm{~d}, 1 \mathrm{H}, \mathrm{H}-7, J=8.90$ $\mathrm{Hz}), 7.65(\mathrm{dd}, 2 \mathrm{H}, \mathrm{Ar}-\mathrm{H}, J=7.50,8.00 \mathrm{~Hz}), 7.72(\mathrm{dd}, 1 \mathrm{H}, \mathrm{Ar}-\mathrm{H}, J$ $=7.00,7.50 \mathrm{~Hz}), 7.79(\mathrm{dd}, 1 \mathrm{H}, \mathrm{Ar}-\mathrm{H}, J=7.00,7.50 \mathrm{~Hz}), 7.85(\mathrm{~d}$, $1 \mathrm{H}, \mathrm{H}-7^{\prime}, J=8.20 \mathrm{~Hz}$ ), 8.04 (d, $\left.1 \mathrm{H}, \mathrm{H}-4^{\prime}, J=7.50 \mathrm{~Hz}\right), 8.17$ (d, $1 \mathrm{H}$, $\mathrm{H}-9, J=8.20 \mathrm{~Hz}), 8.54(\mathrm{~d}, 1 \mathrm{H}, \mathrm{H}-12, J=8.20 \mathrm{~Hz}), 8.58(\mathrm{~d}, 1 \mathrm{H}$, $\mathrm{CH}=\mathrm{N}, J=1.40 \mathrm{~Hz}), 8.92(\mathrm{~d}, 1 \mathrm{H}, \mathrm{H}-4, J=1.40 \mathrm{~Hz})$; anal. calcd for $\mathrm{C}_{26} \mathrm{H}_{17} \mathrm{~N}_{5} \mathrm{O}_{3} \mathrm{~S}$ (479.51): C, 65.13; H, 3.57; N, 14.61; S, 6.69\%. Found: C, 65.16; H, 3.56; N, 14.65; S, 6.66\%.

2-(benzo[d]thiazol-2-yl)-12-(piperidin-1-yl)-4,12-dihydro-3Hbenzo[7,8]chromeno[ $[4,3-b]$ pyridin-3-one $(7)$.

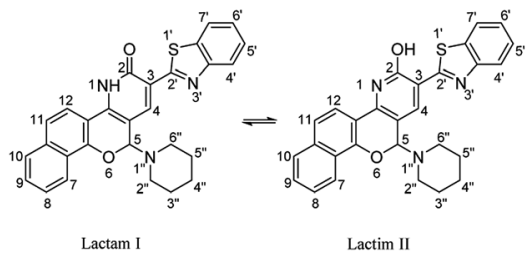

Note: both of keto and enol forms were only observed in NMR analyses due to the use of trifluoroacetic acid as solvent which might induce this tautomerization process.

Yellow crystals; (307 mg, 66\%); $\mathrm{mp}>330{ }^{\circ} \mathrm{C}$; IR $(\mathrm{KBr}, \nu /$ $\left.\mathrm{cm}^{-1}\right)$ : 3350-3460 (NH, broad), 3064 (aromatic $\mathrm{CH}$ ), 2931-2816 (aliphatic $\mathrm{CH}), 1643(\mathrm{C}=\mathrm{O}), 1604(\mathrm{C}=\mathrm{N}), 1560(\mathrm{C}=\mathrm{C}) ;{ }^{1} \mathrm{H}$ NMR (500 MHz, TFA): $\delta$ (ppm) 1.49-2.16 (m, 12H, H-3", $4^{\prime \prime}, 5^{\prime \prime}$, I \& II), 3.09-4.04 (m, 8H, H-2", H-6" , I \& II), 6.97 (s, 2H, H-4, I \& II), 7.85 (dd, 2H, Ar-H, $J=7.49,7.51 \mathrm{~Hz}$, I \& II), 7.92 (m, 4H, Ar-H, I \& II), 7.97 (d, 4H, Ar-H, I \& II) 8.05 (m, 2H, Ar-H, I \& II), 8.12 (m, 2H, Ar-H, I \& II), 8.22 (m, 2H, Ar-H, I \& II), 8.29 (m, 2H, Ar-H, I \& II), 8.46 (m, 2H, H-7, I \& II), 9.03 (s, 2H, H-4, I \& II); EI-MS m/z (\%): $465.57\left[\mathrm{M}^{+}\right]$(45.76), 462.54 (64.03), 331.08 (59.94), 315.14 (45.02), 99.57 (69.91), 83.35 (100.00), 59.43 (82.74), 55.20 (76.75); ${ }^{13} \mathrm{C}$ NMR (126 MHz, TFA): $\delta$ (ppm) 22.91, 23.34, 24.39, 24.68, 24.82, 48.52, 51.84, 52.98, 68.60, 91.64, 105.22, 109.30, 114.16, 114.32, 119.54, 120.53, 122.93, 123.98, 124.69, 124.90, 125.15, 125.38, 125.62, 128.92, 130.94, 131.22, 131.39, 131.75, 132.75, 132.93, 133.06, 133.21, 133.92, 134.22, 135.79, 137.48, 140.42, 140.66, 141.64, 142.14, 144.41, 146.13, 148.36, 153.73, 168.88; anal. calcd for $\mathrm{C}_{28} \mathrm{H}_{23} \mathrm{~N}_{3} \mathrm{O}_{2} \mathrm{~S}$ (465.57): C, 72.24; H, 4.98; N, 9.03; S, 6.89\%. Found: C, 72.22; H, 4.99; N, 9.01, S, 6.87\%.

(1-Amino-5-(benzo[d]thiazol-2-yl)-6-imino-1,6dihydropyridin-3-yl)(1-hydroxynaphthal en-2-yl)methanone (8).

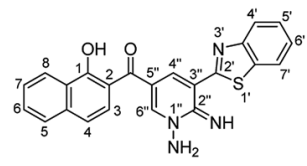

Pale yellow crystals; (301 mg, 73\%); mp 240-241 ${ }^{\circ} \mathrm{C}$; IR (KBr, $\left.\nu / \mathrm{cm}^{-1}\right): 3460-3100\left(\mathrm{OH}, \mathrm{NH}_{2}\right.$ broad), $3129(\mathrm{NH}), 1648(\mathrm{C}=\mathrm{O})$, $1628(\mathrm{C}=\mathrm{N}), 1599(\mathrm{C}=\mathrm{C}) ;{ }^{1} \mathrm{H}$ NMR $\left(500 \mathrm{MHz}, \mathrm{DMSO}-d_{6}\right)$ : $\delta(\mathrm{ppm}) 7.29\left(\mathrm{~s}, 2 \mathrm{H}, \mathrm{NH}_{2}\right), 7.51(\mathrm{~d}, 1 \mathrm{H}, \mathrm{H}-3, J=8.20 \mathrm{~Hz}), 7.57$ (dd, $\left.1 \mathrm{H}, \mathrm{H}-6^{\prime}, J=7.49,7.51 \mathrm{~Hz}\right), 7.61-7.65(\mathrm{dd}, 2 \mathrm{H}, \mathrm{Ar}-\mathrm{H}), 7.66(\mathrm{~d}$, $\left.1 \mathrm{H}, \mathrm{H}-4^{\prime}, J=8.90 \mathrm{~Hz}\right), 7.73\left(\mathrm{dd}, 1 \mathrm{H}, \mathrm{H}-5^{\prime}, J=7.49,7.51 \mathrm{~Hz}\right), 7.96$ $(\mathrm{d}, 1 \mathrm{H}, \mathrm{H}-4, J=8.20 \mathrm{~Hz}$ ), 8.22 (d, $1 \mathrm{H}, \mathrm{H}-8, J=8.20 \mathrm{~Hz}$ ), 8.39 (d, $1 \mathrm{H}, \mathrm{H}-5, J=8.20 \mathrm{~Hz}), 8.68\left(\mathrm{~d}, 1 \mathrm{H}, \mathrm{H}-4^{\prime \prime}, J=1.40 \mathrm{~Hz}\right), 8.78(\mathrm{~s}, 1 \mathrm{H}$, H-6"), 10.18 (brs, 1H, OH), 12.30 (s, 1H, NH); EI-MS m/z (\%): $412.34\left[\mathrm{M}^{+}\right]$(8.22), 350.34 (42.07), 305.04 (73.80), 240.95 (100.00), 221.44 (77.21), 107.52 (50.84), 83.05 (76.40); ${ }^{13} \mathrm{C}$ NMR (126 MHz, DMSO- $\left.d_{6}\right): \delta(\mathrm{ppm}) 114.79,114.91,119.21,121.40$, 122.24, 123.21, 123.56, 124.73, 126.08, 126.17, 126.83, 127.16, 127.57, 129.86, 133.17, 136.64, 139.87, 144.94, 151.63, 151.84, 158.63, 163.06, 191.91; anal. calcd for $\mathrm{C}_{23} \mathrm{H}_{16} \mathrm{~N}_{4} \mathrm{O}_{2} \mathrm{~S}$ (412.47): C, 
66.98; H, 3.91; N, 13.58; S, 7.77\%. Found: C, 66.95; H, 3.93; N, $13.59 ; \mathrm{S}, 7.79 \%$.

(8-(Benzo[d]thiazol-2-yl)-2-thioxo-2,3-dihydro-[1,2,4] triazolo [1,5-a]pyridin-6-yl)(1-hydroxynaphthalen-2-yl)methanone (10).

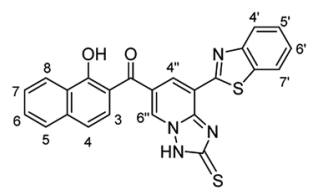

Orange crystals; (241 mg, 53\%); mp $264{ }^{\circ} \mathrm{C}$; IR ( $\left.\mathrm{KBr}, \nu / \mathrm{cm}^{-1}\right)$ : 3450-3300 (OH, broad), $3293(\mathrm{NH}), 3054$ (aromatic $\mathrm{CH}$ ), 1637 $(\mathrm{C}=\mathrm{N}), 1593(\mathrm{C}=\mathrm{C}) ;{ }^{1} \mathrm{H}$ NMR $\left(500 \mathrm{MHz}, \mathrm{DMSO}-d_{6}\right): \delta(\mathrm{ppm})$ 7.48-7.50 (m, 2H, Ar-H), 7.57 (dd, $1 \mathrm{H}, \mathrm{H}-7, J=7.00,8.00 \mathrm{~Hz}$ ), $7.63(\mathrm{dd}, 1 \mathrm{H}, \mathrm{Ar}-\mathrm{H}, J=7.00,8.50 \mathrm{~Hz}), 7.67(\mathrm{dd}, 1 \mathrm{H}, J=1.50,7.60$ $\mathrm{Hz}$ ), 7.73 (dd, 1H, H-6, $J=7.00,8.00 \mathrm{~Hz}$ ), 7.96 (d, 1H, H-5, $J=$ $8.20 \mathrm{~Hz}), 8.14(\mathrm{dd}, 2 \mathrm{H}, \mathrm{Ar}-\mathrm{H}, J=8.00,9.00 \mathrm{~Hz}), 8.38$ (d, $1 \mathrm{H}, \mathrm{Ar}-$ $\mathrm{H}, J=8.20 \mathrm{~Hz}), 8.40\left(\mathrm{~d}, 1 \mathrm{H}, \mathrm{H}-4^{\prime \prime}, J=2.00 \mathrm{~Hz}\right), 8.59$ (d, $1 \mathrm{H}, \mathrm{H}-6^{\prime \prime}$, $J=2.00 \mathrm{~Hz}$ ), 8.76 (brs, 2H, $\mathrm{NH}_{2}$ ), 12.85 (s, 1H, OH); EI-MS $m / z$ (\%): $471.08\left[\mathrm{M}^{+}\right]$(14.29), 420.45 (18.15), 263.38 (19.92), 147.26 (37.62), 102.65 (21.94), 97.34 (38.44), 67.14 (100.00), 60.16 (52.60), 53.36 (84.10); anal. calcd for $\mathrm{C}_{24} \mathrm{H}_{17} \mathrm{~N}_{5} \mathrm{O}_{2} \mathrm{~S}_{2}$ (471.55): C, 61.13; H, 3.63; N, 14.85; S, 13.60\%. Found: C, 61.15; H, 3.64; N, $14.84 \mathrm{~S}, 13.56 \%$.

\section{Computational prediction of biological activities of oxocine derivatives $3 a-e$ and 6}

The $2 \mathrm{D}$ chemical structures of the oxocine derivatives $\mathbf{3 a}-\mathbf{e}$ and 6 were drawn using both ChemDoodle ${ }^{36}$ and Marvin Sketch (ChemAxon, Version 18.30). After that SwissADME predictor software (http://www.swissadme.ch/) was used to convert the 2D structures into SMILEY mode. ${ }^{37}$ The biological activities of the synthesized products were predicted using PASS online software. The main target of PASS (prediction of activity spectra for biologically active substances) is prediction of the most probable kind of biological activity from the chemical structure. It reflects all biological activities that arise from interactions with biological entities among the compounds from the viable database. In this study, PASS develops prediction of biological activities with the probabilities of $\mathrm{Pa}$ (to be active) and $\mathrm{Pi}$ (to be inactive) values. ${ }^{38}$

\section{Conflicts of interest}

The authors have no conflict of interest to mention.

\section{References}

1 J. Cossy, M. Brimble and M. Cordes, Synthesis of Saturated Oxygenated Heterocycles, Springer, 2014.

2 B. Harrison and P. Crews, J. Org. Chem., 1997, 62, 2646-2648. 3 A. Arnone, G. Nasini, W. Panzeri, O. V. d. Pava and L. Malpezzi, J. Nat. Prod., 2007, 71, 146-149.

4 W. Steglich, Pure Appl. Chem., 1989, 61, 281-288.

5 L.-c. Fu, X.-a. Huang, Z.-y. Lai, Y.-j. Hu, H.-j. Liu and X.-l. Cai, Molecules, 2008, 13, 1923-1930.
6 T. Ghosh, Synth. Commun., 2018, 48, 1338-1345.

7 L. Liang, E. Li, X. Dong and Y. Huang, Org. Lett., 2015, 17, 4914-4917.

8 T. Ghosh, New J. Chem., 2017, 41, 2927-2933.

9 R. K. Boeckman, J. Zhang and M. R. Reeder, Org. Lett., 2002, 4, 3891-3894.

10 S. K. Chattopadhyay, S. Karmakar, T. Biswas, K. Majumdar, H. Rahaman and B. Roy, Tetrahedron, 2007, 63, 3919-3952.

11 M. Bratz, W. H. Bullock, L. E. Overman and T. Takemoto, J. Am. Chem. Soc., 1995, 117, 5958-5966.

12 K. Nicolaou, D. McGarry, P. Somers, B. Kim, W. Ogilvie, G. Yiannikouros, C. Prasad, C. Veale and R. Hark, J. Am. Chem. Soc., 1990, 112, 6263-6276.

13 S. Ma and E.-i. Negishi, J. Org. Chem., 1994, 59, 4730-4732.

14 N. Ortega, T. Martín and V. S. Martín, Org. Lett., 2006, 8, 871873.

15 S. K. Mandal and S. C. Roy, Tetrahedron, 2007, 63, 1134111348.

16 M. Sasaki, A. Hashimoto, K. Tanaka, M. Kawahata, K. Yamaguchi and K. Takeda, Org. Lett., 2008, 10, 1803-1806. 17 M. A. Ibrahim, ARKIVOC, 2008, (xvii), 192-204.

18 J. Li, J. M. Suh and E. Chin, Org. Lett., 2010, 12, 4712-4715. 19 H.-H. Liao and R.-S. Liu, Chem. Commun., 2011, 47, 13391341.

20 A. Thakur and J. Louie, Acc. Chem. Res., 2015, 48, 2354-2365. 21 G. Kim, T. i. Sohn, D. Kim and R. S. Paton, Angew. Chem., Int. Ed., 2014, 53, 272-276.

22 M. Ibrahim, N. El-Gohary, S. Ibrahim and S. Said, Chem. Heterocycl. Compd., 2015, 50, 1624-1633.

23 M. A. Ibrahim and T. E.-S. Ali, Turk. J. Chem., 2015, 39, 412425.

24 S. P. Alexander, E. Kelly, N. Marrion, J. A. Peters, H. E. Benson, E. Faccenda, A. J. Pawson, J. L. Sharman, C. Southan and O. P. Buneman, Br. J. Pharmacol., 2015, 172, 5729-5743.

25 M. Frisch, G. Trucks, H. Schlegel, G. Scuseria, M. Robb, J. Cheeseman, G. Scalmani, V. Barone, B. Mennucci and G. Petersson, Gaussian 09, Revision D.01, Gaussian, Inc., Wallingford CT USA, 2009.

26 A. D. Becke, Phys. Rev. A: At., Mol., Opt. Phys., 1988, 38, 30983100 .

27 C. Lee, W. Yang and R. G. Parr, Phys. Rev. B: Condens. Matter Mater. Phys., 1988, 37, 785-789.

28 N. Godbout, D. R. Salahub, J. Andzelm and E. Wimmer, Can. J. Chem., 1992, 70, 560-571.

29 S. Gupta and J. M. Khurana, Green Chem., 2017, 19, 41534156.

30 M. A. Ibrahim and A.-S. Badran, ARKIVOC, 2018, (vii), 214224, DOI: 10.24820/ark.5550190.p010.745.

31 A good agreement was found between the experimental and predicted IR spectra of compound 3a which support the reliability of the calculated results. Predicted IR absorptions: $3450 \mathrm{~cm}^{-1} \quad(\mathrm{OH}), 3280 \mathrm{~cm}^{-1} \quad(\mathrm{NH})$, $33105 \mathrm{~cm}^{-1}$ (aromatic $\left.\mathrm{CH}\right), 1608 \mathrm{~cm}^{-1}(\mathrm{C}=\mathrm{N}), 1530 \mathrm{~cm}^{-1}$ $(\mathrm{C}=\mathrm{C})($ see ESI $\dagger$ ).

32 S. E. Koops, B. C. O'Regan, P. R. Barnes and J. R. Durrant, J. Am. Chem. Soc., 2009, 131, 4808-4818. 
33 Q.-H. Yao, L. Shan, F.-Y. Li, D.-D. Yin and C.-H. Huang, New J. Chem., 2003, 27, 1277-1283.

34 M. Al-Eid, S. Lim, K. Park, B. Fitzpatrick, C. Han, K. Kwak, J. Hong and G. Cooke, Dyes Pigm., 2014, 104, 197-203.
35 X. Liu, Z. Cao, H. Huang, X. Liu, Y. Tan, H. Chen, Y. Pei and S. Tan, J. Power Sources, 2014, 248, 400-406.

36 M. C. Burger, J. Cheminf., 2015, 7, 35.

37 A. Daina, O. Michielin and V. Zoete, Sci. Rep., 2017, 7, 42717. 38 S. Parasuraman, J. Pharmacol. Pharmacother., 2011, 2, 52-53. 